\title{
Metacognition and Second/Foreign Language Learning
}

\author{
Saeid Raoofi ${ }^{1}$, SweeHengChan ${ }^{1}$, Jayakaran Mukundan ${ }^{2} \&$ Sabariah Md Rashid ${ }^{1}$ \\ ${ }^{1}$ Department of English, Faculty of Modern Languages and Communication, University Putra Malaysia (UPM), \\ Malaysia \\ ${ }^{2}$ Department of Language and Humanities Education, Faculty of Educational Studies, Universiti Putra Malaysia \\ (UPM), Malaysia
}

Correspondence: Saeid Raoofi, Department of English, Faculty of Modern Languages and Communication, University Putra Malaysia (UPM), 43400 UPM Serdang, Selangor, Malaysia. Tel: 60-112-361-8880. E-mail: raoofisaeed2020@yahoo.com

Received: October 17, 2013 Accepted: October 25, 2013 Online Published: December 5, 2013

doi:10.5539/elt.v7n1p36 URL: http://dx.doi.org/10.5539/elt.v7n1p36

\begin{abstract}
Metacognition appears to be a significant contributor to success in second language (SL) and foreign language (FL) learning. This study seeks to investigate empirical research on the role metacognition plays in language learning by focusing on the following research questions: first, to what extent does metacognition affect SL/FL learning? Second, what are the factors shown to influence metacognition of learners in the area of second/foreign language learning? Data from 33 studies published between 1999 and 2013 were coded based on a coding scheme adapted from previous systematic reviews (e.g., Norris \& Ortega, 2001; Plonsky, 2011). The findings of the review show that the metacognitive interventions have the possibility to promote language performance, but, on the whole, mixed evidence was found for the effectiveness of the intervention in enhancing metacognitive awareness/strategy use. The results also indicate that several factors appeared to affect L2 learners' metacognition. This review expands our understanding of the role of metacognition in language learning and will lead to pedagogical implications for SL/FL learning and teaching. Limitations of the existing studies and directions for future research are also discussed.
\end{abstract}

Keywords: metacognitive strategies, metacognitive awareness, second/foreign language learning

\section{Introduction}

Learning strategies play an important role in the success of language learning.Interest in language learning strategies has grown since the mid-1970s (Chamot \& Kupper, 1989; Cohen, 1996; Cohen \& Macaro, 2007; Macaro, 2006; Nisbet \& Shucksmith, 1986; O’Malley et al., 1985, 1989; Oxford, 1990, 2011; Oxford \& Nyikos, 1989; Rubin, 1975). Research in the field of language learning strategies has focused on successful learners; ample attention has been directed towards what successful language learners do when they tackle the problems they face in their learning. Indeed, successful L2 learners employ different strategies for different tasks; they select their strategies for a particular task based on the task requirements and specifications (Chamot \& El-Dinary, 1999; Khaldieh, 2000; O’Malley \& Chamot, 1990) SLAresearchers unanimously agree that good language learners use a wide variety of effective techniques and tactics to perform their learning tasks in a given situation. Researchers were also interested to focus on how language learners manage to use a plethora of strategies to perform different tasks within different contexts (Ellis, 1994; Hsiao \& Oxford, 2002).

There are different taxonomies of language learning strategies (Cohen, 1998; O’Malley \& Chamot, 1990; Oxford 1990; Wenden \& Rubin, 1987). Two of these, Oxford's (1990) strategy system and O'Malley and Chamot's (1990) strategy taxonomy have received abundant attention. Oxford's (1990) strategy taxonomy which encompasses six categories includes cognitive strategies, metacognitive, memory, compensatory, social and affective strategies. However O'Malley and Chamot (1990) have classified them into only three types, namely, cognitive, metacognitive and scoioaffective strategies.

Despite abundant research on learning strategies, little research has investigated language strategy instruction. Research reveals that explicit strategy instruction is an effective way to enhance learners' awareness about the learning strategies, particularly in the case of less successful learners because strategy training provides opportunities for learners to incorporate relevant strategies into their task learning, with the training focusing on 
strategy awareness, strategy selection and practice, feedback and reflection on strategies (Dörnyei, 2006). On the whole, previous research on strategy training has investigated the effects of strategy instruction on the following variables in the area of second/foreign language learning: self-efficacy and self-esteem (Pintrich \& Schunk, 2002; Rossiter, 2003), motivation (Nunan, 1997), oral communication (Cohen, Weaver \& Li, 1998; Lam \& Wong, 2000; Naughton, 2006), reading (Kern, 1989; Zentoz, 2012), listening (Moradi, 2013; Vandergrift, 2003), writing (Cresswell, 2000; McMullen, 2009), and vocabulary (Cohen \& Aphek, 1981; Lawson \& Hogben, 1998).

In the SLA literature, among different types of learning strategies, metacognitive strategies have been reported to play a more important role than other strategies in the successful language learning; these strategies help learners to regulate their own learning, and to accomplish different language tasks in different contexts effectively (Pintrich, 2002).

\section{Metacognition}

Various terms including self-management, metamentation, meta-learning, metacomponents, have been used to represent the concept of metacognition by researchers. Metacognition has been defined in various ways by different researchers (Jacobs \& Paris, 1987; Flavell, 1976, 1979; Georghiades, 2004; Schraw, 1994; Swanson, 1990; Wenden, 1998). The concept ofmetacognition was first proposed by Flavell (1976), and it was defined as “one's knowledge concerning one's own cognitive processes and products or anything related to them" (p. 232). In his later research, Flavell (1979) redefined metacognition as individuals' information and awarenessabout their owncognition.

Although there are numerous definitions of metacognition in the literature, all of the definitions share a common core which refers to individuals' awareness and management of their learning processes. What is noteworthy about the concept of Metacognition is that it is composed of two underlying components: metacognitive awareness and metacognitive strategies. Metacognitive awareness is the learners' knowledge about their learning, while metacognitive strategies refer to learners' regulation and management of their learning which encompasses a wide range of activities: selecting the most useful strategies for a particular task; planning, monitoring, regulation and evaluation of learning (Schraw et al., 2006).

Research on metacognition indicates that metacognitive strategy/knowledge is closely related to success in Second/foreign language learning. Learners who are equipped with metacognitive strategies, are aware of their learning and they know how and when to employ the most relevant strategies to accomplish a given task; they know how to accomplish a particular task in the most effective way. They plan their learning in advance, monitor their learning during the task performance, and evaluate their learning after task accomplishment (Zhang \& Goh, 2006). Furthermore, learners who are metacognitive in their learning seem to be more self-regulated learners. Enhancing students' self-directed learning and autonomy has received considerable attention throughout educational institutions in recent years. Metacognitive instruction is an effective way to develop to develop learner-centeredness and learner autonomy. Numerous studies have demonstrated that the instruction of metacogintive strategies helps learners to become more self-regulated, self-directed and successful in their learning (Goh, 1997; O’Malley \& Chamot, 1990; Vandergrift, 2002, 2003).

In recent years, several review studies have focused on L2 learning strategies (Plonsky, 2011; Goh, 2008; Wenden, 1998; Carrell, 1998; Taylor et al., 2006; Rivera-Mills \& Plonsky, 2007; Chamot, 2005). While, most of these reviews have addressed general language learning strategies, tworeviews are exclusive to L2 metacognition. Apart from Wenden's (1998) theoretical review of metacognitive knowledge and Goh's (2008) review on metacognitive instruction for L2 listening development, there has been no review of metacognitive strategies and awareness in the literature of second language acquisition. Furthermore, because of a substantial number of recently published studies that investigated the L2 metacognition, it appears to be essential to do a study review to obtain a deep understanding of the recent changes and the extent of investigation on L2 metacognitive awareness and strategies. Since the last comprehensive review on metacognition and L2 learning was performed in 1998, this review focuses on studies published after 1998.

\section{Method}

\subsection{Search Procedures and Criteria for Inclusion}

For the current review, research synthetic techniques were employed to gather a thorough if not exhaustive collection of current studies on metacognition in the area of second/foreign language learning. The research domain encompasses all published qualitative and quantitative primary research investigating the role of metacognition in language learning. The search for empirical studies was carried out in three stages. First, we searched the following electronic databases: SCOPUS, ERIC, Academic Search Premier, PsycINFO and Google 
Scholar to locate all possible primary studies aimed at investigating the role of metacognition in second /foreign language learning. We searched online using the combinations of the following key terms: metacognitive, metacognition, second language and foreign language for the articles published between 1999 and 2012. This initial search yielded a total of 76 studies. Out of these, 29 empirical articles that met the following inclusion criteria were selected for this review: 1 . The context of study had to be second/foreign language learning; 2 . Metacognition had to be the one of the main variables of the study; 3. Research on factors influencing metacognition or factors influenced bymetacognition had to be described.

Studies that were not written in English and studies that were not empirical were also excluded in this synthesis. Studies that did not use appropriate methods to measure metacognition were not also included, nor were book chapters, master and doctoral dissertations included. In the second stage, to ensure a thorough search, the reference sections of the selected studies were reviewed for additional relevant studies and 4 articles that met the selection criteria were found. Finally a total of 33 articles from the following professional journals were identified for this review. Applied Linguistics, Language Learning, Language Awareness, Language Testing, Language and Education, Foreign Language Annals, Canadian Modern Language Review, The Modern Language Journal, TESOL Quarterly, Metacognition and Learning, System, Journal of Educational Psychology, ELT Journal, Asia Pacific Education Review, International Education Journal, Journal of Adolescent \& Adult Literacy, Learning and Individual Differences, Procedia Social and Behavioral Sciences, Educational Technology \& Society, and Asian EFL Journal.

\subsection{Coding and Analysis}

Once selected, the empirical studies were coded based on a coding scheme (see Table 1) which was developed through a process that considered the data codingmethodsused in previous reviews in the area of SLA (e.g., Norris \& Ortega, 2001; Plonsky, 2011; Spada \& Tomita, 2010). With the intention to analyse the studies, the study characteristics were defined, coded and classified into several categories relative to the review questions. To ensure the reliability of data coding, a second rater, with great expertise in SLA, coded one fourth of the studies independently of the researchers. There was $97 \%$ agreement between the two raters.

Since the selected studies differ in design and methodological feature, we chose to conduct a narrative review. This type of review provides in-depth knowledge and up-to-date information about a specific theme or topic (Dochy et al., 2003). Furthermore, narrative review highlights the limitations of the current studies and suggests directions for future research. Creswell (1994) states the objective of a review is to summarize the existing research on a specific topic and to identify the issues that need further investigation.

To perform a systematic narrative review, we described, compared and contrasted the primary studies in a systematic way and approached the study from a holistic and theoretical point of view. In this review, the following steps were taken to evaluate and analyse the selected studies. First, based on the characteristics of the type of the study, the studies were divided into two categories: studies with intervention and studies without intervention. Second, the intervention category was classified into two subcategories: studies with control group and studies without control group; and the without-intervention group was broken into several subcategories based on the common themes and coded characteristics. Third, subcategories were compared and contrasted to draw the similarities and differences. In the last step, we analysed the studies and discus the results in addressing the research questions. That is, the effectiveness of metacognition on second/foreign language learning and the investigation of factors and variables have been found to be related to metacognition.

Table 1. Coding scheme for primary studies

\begin{tabular}{llll}
\hline Variables & Values & \\
\hline Study & & \\
Year of publication & & \\
Language domain & Second & Foreign & \\
$\begin{array}{l}\text { Second or foreign language } \\
\text { Participants' age (average) }\end{array}$ & & & \\
Educational institution & Elementary & High school & University \\
Country & & & \\
\hline
\end{tabular}




\begin{tabular}{llll}
\hline Participants' L1 & & \\
Participants' L2 & Low & Middle & High \\
$\begin{array}{l}\text { Proficiency level } \\
\text { Type of design }\end{array}$ & Yes & No \\
Intervention? & & \\
Length of intervention & Yes & No \\
(For studies with intervention) Control group? & & \\
$\begin{array}{l}\text { Samplesize } \\
\text { (For intervention studies) N-size treatment group }\end{array}$ & & \\
$\begin{array}{l}\text { Measure/instrument } \\
\text { (For non-intervention studies) variables of the study }\end{array}$ & \\
\end{tabular}

\section{Results and Discussion}

Using several search strategies and ancestry method, we selected 33 studies published between 1999 and 2013 for this review. Based on identified themes, the selected studies were classified into two main categories: effects of metacognition and factors affecting metacognition; and within each category there were several subdivisions, as shown in table 2 .

\subsection{General Characteristics of the Selected Studies}

The selected studies for the current review encompass research carried out between 1999 and 2013: 18\% between 1999 and 2003, $36 \%$ between 2004 and 2008, 46\% between 2009 and 2013 (until September). The selected research was conducted in in following educational contexts: elementary school (two studies), high school (eight studies), university (eighteen studies), adult not university (three studies) and two studies involved both university and high school students. Our review also shows that only a few studies have investigated metacognition in relation to learning a SL/FL other than English, most of the research studies were conducted with participants learning English as a second/foreign language. On the whole, researchers have examined the role of metacognition in learning seven languages as a foreign or second language: English (26 studies, approximately $79 \%$ of the total 33) French (5 studies, 15\%), Spanish (one study, 3\%) and German (one study, 3\%). For data collection, primary researchers employed a variety of different instruments to measure metacognition in L2 learning. Such instruments ranged from a questionnaire to think aloud protocols. Questionnaire has been the most widely used tool for evaluating the metacognitive awareness and metacognitive strategy use in L2 learning. Although, the studies vary in the type of tools for measuring the construct of metacognition, all of the studies were explicitly based on or related to Flavell's (1979) definition of metacognition as mentioned earlier.

Table 2. Categorization of the selected studies based on identified themes

\begin{tabular}{ll}
\hline Category & Sub-category \\
\hline Effects of metacognition & 1. Effects of metacognitive instruction on \\
a) Metacognitive strategy use/ awareness & b) Language performance \\
2. Metacognition as a predictor of language performance & 3. Effects of metacognition on affective domain \\
Factors affecting metacognition & 2. Language proficiency \\
& 3. Bilingualism \\
& 4. Learning styles \\
5. L1 metacognitive knowledge/strategy use
\end{tabular}




\subsection{Effects of Metacognition}

On the whole, past empirical research that examined the effects of metacognition on language learning can be divided into three groups: effects of metacognitive instruction, metacognition as a predictor of language performance, and effects of metacognition on affective domain. Within the effects of metacognitive instruction, there are two subdivisions: the effects of metacognitive instruction on language performance and the effects of metacognitive instruction on metacognitive awareness/metacognitive strategy use.

\subsubsection{Effects of Metacognitive Instruction on Language Performance}

Of the 33 studies finally selected, 8 studies investigated whether metacognitive instruction could enhance language performance (see Table 3). This group of studies was composed of 8 experimental studies: 6 quasi experimental studies (Graham \& Macaro, 2008; Lam, 2009; Nakatani, 2005; Nguyen \& Gu, 2013; Vandergrift \& Tafaghodtari, 2010; Zenotz, 2012) and 2 pre-experimental studies in which the interventions were carried out without control group (Cross, 2011; Guh \& Taib, 2006). All of the studies reported that metacognitive treatment has significantly improved language performance. Although evidence from these studies showed that metacognition instruction in different domains of language appeared to promote language learning, none of these studies were true experimental that is, in these studies participants were not randomly assigned to groups (treatment and control) and extraneous variables were not highly controlled. Thus, in the two without-control group studies (Cross, 2011; Guh \& Taib, 2006), it cannot be assumed that the improvement in language performance is due to the effects of metacognitive instruction because the researchers used interventions without control group and they also had little control over extraneous variables posing threats to internal validity. With regard to intervention duration, none of the interventions lasted longer than a semester, for example in Zenotz's (2012) study, metacognitive instruction lasted fourteen hours distributed over a semester. Furthermore, exceptfor the study carried out by Graham and Macaro (2008), all of the other studies only investigated the short-effects of intervention and they did not examine the effectiveness of strategy instruction over the following semester or year. Additionally, as shown in table 3, several studies (Cross, 2011; Guh \& Taib, 2006; Lam, 2009) used only a small sample size which may have threatened the external validity of these studies (generalization of the findings).

Table 3. Studies investigating the effects of metacognitive instruction on L2 performance

\begin{tabular}{|c|c|c|c|c|c|c|c|}
\hline Study & $\mathrm{n}$ & L2 & L1 & Proficiency & Age & $\begin{array}{l}\text { Control } \\
\text { Group }\end{array}$ & $\begin{array}{l}\text { Language } \\
\text { Domain }\end{array}$ \\
\hline Lam (2009) & 40 & English (SL) & Chinese & High & $13-14$ & Yes & Speaking \\
\hline Zenotz (2012) & 143 & English (FL) & Spanish & Not reported & $21-22$ & Yes & Reading \\
\hline Cross (2011) & 20 & English (FL) & Japanese & High & $22-55$ & No & Listening \\
\hline Nakatani (2005) & 62 & English (FL) & Japanese & Mix & $18-19$ & Yes & Speaking \\
\hline $\begin{array}{l}\text { Nguyen and Gu } \\
\text { (2013) }\end{array}$ & 91 & English (FL) & Vietnamese & High & $20-22$ & Yes & Writing \\
\hline $\begin{array}{l}\text { Guh and Taib } \\
\text { (2006) }\end{array}$ & 10 & English (SL) & Not reported & Mix & $11-12$ & No & Listening \\
\hline $\begin{array}{l}\text { Vandergrift and } \\
\text { Tafaghodtari } \\
\text { (2010) }\end{array}$ & 106 & French (SL) & English & Low \& mid & Undergraduates & Yes & Listening \\
\hline $\begin{array}{l}\text { Graham and } \\
\text { Macaro (2008) }\end{array}$ & 68 & French (SL) & English & Low & $16-17$ & Yes & Listening \\
\hline
\end{tabular}

\subsubsection{Effects of Metacognitive Instruction on the Metacognitive Awareness/Strategy Use}

Table 3 provides the characteristics of 9 studies that have investigated the impact of metacognitive training on metacognitive awareness or strategy use. Results reported of these studies are inconsistent. Of these studies, 4 studies (Cross, 2010; Guh \& Taib, 2006; Vandergrift, 2002, 2003) were conducted without control group. These four studies reported that the intervention helped the learners to develop their metacognition about L2 leaning. However, in these studies, there were many uncontrolled factors affecting the internal validity, that is, the growth 
in metacognition might have been caused by some extraneous factors (e.g., prior knowledge, intelligence, L2 motivation) rather than by the intervention. Furthermore, these studies utilized qualitative techniques (e.g., open-ended questions and interview) to analyse the effects of intervention treatments and hence it was not feasible to calculate an overall mean effect size for these interventions.

Table 4. Studies investigating the effects of metacognitive instruction on the metacognitive awareness/strategy

\begin{tabular}{|c|c|c|c|c|c|c|c|}
\hline Study & $\mathrm{n}$ & L2 & L1 & Proficiency & Age & $\begin{array}{l}\text { Control } \\
\text { Group }\end{array}$ & $\begin{array}{l}\text { Language } \\
\text { Domain }\end{array}$ \\
\hline Vandergrift (2003) & 41 & French (SL) & English & Low & Undergraduates & No & Listening \\
\hline Vandergrift (2002) & 420 & French (SL) & English & Low & $10-12$ & No & Listening \\
\hline Guh and Taib (2006) & 10 & English (SL) & Not reported & Mix & $11-12$ & No & Listening \\
\hline Lam (2009) & 40 & English (SL) & Chinese & High & $13-14$ & Yes & Speaking \\
\hline Cross (2010) & 12 & English (FL) & Japanese & High & $24-45$ & No & Listening \\
\hline Zenotz (2012) & 143 & English (FL) & Spanish & Not reported & $21-22$ & Yes & Reading \\
\hline $\begin{array}{l}\text { Nguyen and Gu } \\
(2013)\end{array}$ & 91 & English (FL) & Vietnamese & High & $20-22$ & Yes & Writing \\
\hline $\begin{array}{l}\text { Vandergrift and } \\
\text { Tafaghodtari (2010) }\end{array}$ & 106 & French (SL) & English & Low \& mid & Undergraduates & Yes & Listening \\
\hline Thompson (2012) & 35 & Spanish (FL) & English & Mid & Undergraduates & Yes & Reading \\
\hline
\end{tabular}

Other studies (Lam, 2009; Nakatani, 2005; Nguyen \& Gu, 2013; Thompson, 2012; Vandergrift \& Tafaghodtari, 2010; Zenotz, 2012) adopted quasi-experimental research in which researchers investigated the differences in metacognitive awareness or strategy usage between control and treatment groups. Among these studies, only Nguyen \& Gu's (2013) study demonstrated that students who received intervention showed a significantly higher level of metacognitive strategy usage than those in the control group. Although results from these studies (Lam, 2009; Nakatani, 2005; Nguyen \& Gu, 2013; Thompson, 2012; Vandergrift \& Tafaghodtari, 2010; Zenotz, 2012) showed that the treatment group slightly outperformed the control group, the researchers acknowledged the limitations of their research mentioning research instrument, sample size, the use of intact groups and time constrains which may have affected the results.

\subsubsection{Metacognition as a Predictor of Language Performance}

Six studies, within the selected group, examined the relationship between metacognition and language performance (Table 5). Except for Yau's (2009) study, all of the other studies in this category (Bruen, 2001; Phakiti, 2003; Pishghadam \& Khajavy , 2013; Schoonen et al., 2011; van Gelderen et al., 2004) found that metacognition significantly predicts language performance. Yau (2009) found a positive correlation between metacognitive strategies and EFL reading comprehension; however it was not at a significant level. One possible explanation for the insignificant results may concern differences in the breadth of metacognitive strategies among high-performing readers as he mentioned that the successful readers differed in the reported use of metacognitive strategies. With reference to the weaknesses of these studies, aside from Schoonen et al.'s ( 2011) longitudinal investigation, none of the studies have checked whether the use of metacognitive strategies in language performance changes over time, all of these studies measured students' metacognition at one moment of time. Another limitation is that some of the studies (Pishghadam \& Khajavy, 2013; Bruen, 2001; Yau, 2009) have relied on convenience sampling rather than using non-probability to recruit participants. Furthermore, although correlational studies require big samples, the sample size in these studies is relatively small. Consequently, using small samples and non-probability sampling had made the results difficult to generalize as the sample might not have been representative of the population. Additionally, these correlational studies could not determine the cause-and-effect relationship between metacognition and language performance because correlational analyses do not show causal relationship between variables; instead they simply reveal the extent of correlation between variables (Green \& Salkind, 2005). Furthermore, except Yau's (2009) study which used three tools (questionnaire, think-aloud protocol and interviews) to measure metacognition, all the other studies employed only questionnaire for this purpose. 
Table 5. Studies investigating the role of metacognition as a predictor of performance

\begin{tabular}{|c|c|c|c|c|c|c|}
\hline Study & $\mathrm{n}$ & L2 & L1 & Proficiency & Age & Language Domain \\
\hline $\begin{array}{l}\text { Pishghadam and } \\
\text { Khajavy (2013) }\end{array}$ & 143 & English (FL) & Persian & Mid & $10-40$ & General \\
\hline Phakiti (2003) & 384 & English (FL) & Thai & Mix & $17-21$ & Reading \\
\hline $\begin{array}{l}\text { van Gelderen et } \\
\text { al. (2004) }\end{array}$ & 281 & English (FL) & Dutch & Low & $13-14$ & Reading \\
\hline Yau (2009) & 137 & English (FL) & Chinese & Mix & $17-18$ & Reading \\
\hline $\begin{array}{l}\text { Schoonen et al. } \\
\text { (2011) }\end{array}$ & 397 & English (FL) & Dutch & Low & $13-14$ & Writing \\
\hline Bruen (2001) & 100 & German (FL) & English & Mix & $18-22$ & Speaking \\
\hline
\end{tabular}

\subsubsection{Effects of Metacognition on Affective Domain}

Researchers have also sought to examine whether metacognition is related to L2 motivation. Vandergrift (2005) reported that there is a significant relationship between metacognitive strategies and L2 motivation. In his study that involved 51 Canadian high school students learning French as second language, Vandergrift discovered that L2 motivation was significantly correlated with listening metacognitive strategies. Similarly, Manfred (2007) surveyed 193 ESL students aged 16 to 23 in Hong Kong to investigate the interplay between metacognition and L2 motivation. The survey results indicated that metacognitive strategies were significantly associated with L2 integrative and instrumental motivations.

\subsection{Factors Affecting Metacognition}

\subsubsection{Language Proficiency}

In our review of the empirical research, we identified seven studies addressing differences in metacognitive knowledge/strategies among language learners with different levels of language proficiency (Table 4). These studies found that the high proficient learners use more metacognitive knowledge in their learning than less proficient ones. Phakiti (2003) found that highly proficient language learners reported significantly higher usage of metacognitive strategies than the moderately proficient ones, and that, learners with medium proficiency reported more metacognitive strategy use than low-proficient learners. Similarly, the results of a large-scale study of EFL Taiwanese learners (Lai, 2009) revealed that high-level learners reported using metacognitive strategies significantly more than low-level and mid-level ones. Liu (2010) also found that learners with a high level of language proficiency reported higher use of metacognitive strategies than low proficient learners. In addition, Zhang (2001) and Radwan's (2011) investigations yielded similar results to those reported by Liu (2008). In her qualitative study, Victori (1999) reported that good language learners showed more use of metacognitive strategies in their writing than the poor ones. However, Hong-Nam and Leavell (2006) found that mid-level students reported significantly more use of metacognitive strategies than high and low level students. To shed lights on unexpected results, the researchers argued that intermediate students are more conscious of their way of learning than advanced ones, that is, advanced students' usage of metacognitive strategies has becomehabitual and automated, and leading to them beingless conscious of their learning strategies.

With regard to the tools for data collection, not only do all of these studies in this subcategory, used only questionnaire for measuring the construct of metacognition, but also majority of the selected studies. Although, questionnaire is a reliable tool for data collection and it can be easily administered to big samples, it cannot provide in-depth investigation into learners' metacognitive knowledge. The observational method, interview and think aloud protocol have some advantages over the other methods such as self-report instruments, but these tools for assessing metacognition have rarely been used in second language learning domain. This may be related to low functionality of these instruments for classroom environments because problems such as loss of time in interviews, difficulty in learner control in observations, anddistractions caused by think aloud protocols are concerned with implementation of these methods in the classroom settings. However, the use of a combination of both quantitative and qualitative tools seems essential for measuring metacognition as Schraw (2009) stated that a single instrument cannot evaluate metacognition alone. 
Table 6. Studies investigating the effects of language proficiency on metacognition

\begin{tabular}{lllllll}
\hline Study & $\mathrm{n}$ & L2 & L1 & Proficiency & Age & Language Domain \\
\hline $\begin{array}{l}\text { Hong-Nam and } \\
\text { Leavell (2006) }\end{array}$ & 55 & English (SL) & Mixed & Mix & $18-40$ & General \\
Phakiti (2003) & 384 & English (FL) & Thai & Mix & $17-21$ & Reading \\
Lai (2009) & 418 & English (FL) & Chinese & Mix & $18-22$ & General \\
Liu (2008) & 101 & English (FL) & Chinese & Mix & $18-35$ & Listening \\
Radwan (2011) & 128 & English (FL) & Arabic & Mix & Undergraduates & General \\
Zhang (2001) & 10 & English (FL) & Chinese & Low and high & 19 & Reading \\
Victori (1999) & 4 & English (FL) & Spanish & Low and high & $18-21$ & Writing \\
\hline
\end{tabular}

\subsubsection{Educational Level}

Metacognition has also been investigated in relation to educational level within the field of language learning (Table 6) In an investigation into metacognitive strategies of EFL university students in Bahrain, Malcolm (2009) found that Year Four students reported significantly more use of metacognitive strategies in EFL reading than Year One students. These results were in line with those of Khalil's (2005) study. In a study that focused on understanding the differences in the metacognitive strategies among EFL university and high school students in Palestine Khalil (2005) discovered that university students made significantly more use of metacognitive strategies than high school students in their EFL learning. These findings show that a longer duration of L2 learning enhances learners' use of metacognitive strategies. This demonstrates that as L2 learners get older and they gain more language learning experiences, their language proficiency develops and in turn their metacognitive strategy usage increases.

Nevertheless, in a more recent study, Rahimi and Katal (2012) found that EFL high school students reported greater usage of metacognitive listening strategies than EFL university students. They maintained that the findings of the study might be due to EFL students' English proficiency, listening skilfulness, motivation and self-efficacy. These findings were consistent with the results from Chen's (2009) study. In a study that assessed the learning strategies among Taiwanese high school students in grades 7 through 9, Chen (2009) found that students in grades 7 and 8 reported using significantly more metacognitive strategies than ninth graders. Overall, the findings of the studies are contradictory. Khalil (2005) claimed that university students use significantly more metacognitive strategies than high school students while Rahimi and Katal's (2012) study yielded results contrary to those obtained by Khalil (2005). Although there is some evidence supporting the connection between language learners' metacognition and their educational level/age, further research is needed to identify factors affecting this association.

Table 7. Studies investigating the relationship between metacognition and educational level

\begin{tabular}{lllllll}
\hline Study & $\mathrm{n}$ & L2 & L1 & Proficiency & Educational Context & Language Domain \\
\hline Malcolm (2009) & 160 & English (FL) & Arabic & Mix & University & Reading \\
Khalil (2005) & 378 & English (FL) & Arabic & Mix & High school and university & General \\
$\begin{array}{l}\text { Rahimi and Katal } \\
\text { (2012) }\end{array}$ & 238 & English (FL) & Persian & Mix & High school and university & Listening \\
Chen (2009) & 378 & English (FL) & Chinese & Not reported & High school & General \\
\hline
\end{tabular}

\subsubsection{Bilingualism}

Researchers were also interested to investigate whether bilingualism could enhance' metacognitive strategy use in language learning. Research addressing the use of metacognitive strategies by bilingual and monolingual learners has shown that there is a significant difference between bilinguals and monolinguals in metacognitive strategy use. For example, in a study aimed at exploring the differences in metacognitive strategies when reading in English by 141 EFL Moroccan undergraduates who were bilingual (in Arabic and French) and 209 US undergraduates who were native speakers of English, Mokhtari and Reichard (2004) found that Moroccan 
students reported significantly higher metacognitive strategy use than did US students. Hong-Nam and Leavell (2007) examined differences in metacognitive strategies among 848 monolinguals (Korean) and bilinguals (Korean-Chinese) who were learning English as a foreign language; and reported that the use of metacognitive strategies in EFL learning was significantly higher for bilinguals than for monolinguals.

\subsubsection{Learning Styles}

In our review of the empirical research, we found that three studies attempted to examine the effects of learning style on L2 metacognition. Chen's (2009) study of 390 Taiwanese high school students learning English as a foreign language, revealed that learning styles (visual, auditory, kinaesthetic, tactile, group and individual) were significantly correlated to the use of metacognitive strategies. In the same vein, Liu (2008) found a significant relationship between learning styles and metacognitive strategy usage. Liu conducted a study on $101 \mathrm{EFL}$ university students and discovered that there were significant relationships between learning styles (concrete, communicative, analytic, and authority-oriented) and the usage of metacognitive listening strategies.

\subsubsection{First Language Metacognitive Knowledge/Use}

Another line of inquiry into metacognition has focused on the link between L1 and L2 metacognitive knowledge/strategies. For instance, van Gelderen et al. (2007) concluded, from their study of 389 EFL Dutch secondary school students, that metacognitive knowledge in L1 (Dutch) reading played an important but not all encompassing role in the metacognitive knowledge in L2 (English) reading. In the similar vein, Schoonen et al. (2011) demonstrated that learners' metacognitive knowledge about L1 learning influences their metacognitive knowledge about L2 learning. In a longitudinal study of secondary school students in Netherlands, Schoonen et al. (2011) reported that learners' metacognitive knowledge about L2 writing are closely correlated with their metacognitive knowledge about L1 writing. Yau (2009) also investigated the relationship between the use of L1 and L2 metacognition. She conducted a study on 137 EFL eleven-grade students in Taiwan and found that there is a strong link between learners' L1 and L2 metacognitive strategy.

\section{Conclusion}

Metacognition has emerged as a significant construct in SL/FL research over the last 14 years. Researchers within area of language learning have attempted to clarify the role of metacognition in the development of different language skills. Based on the findings of the review, several conclusions about the importance of metacognition in the process of L2 learning can be drawn.

First, it is possible to influence learners' language performance through metacognitive intervention; all of the intervention studies demonstrated that metacognitive training helped learners to achieve improvements in their language performance. Second, evidence from intervention studies also indicates that metacognitive instruction can enhance language learners' metacognitive knowledge/ strategy usage though not significantly in most studies with control group.

Third, in the correlational studies aimed at investigating whether metacognition predicts language performance, researchers reported that it appears to be a relatively strong predictor of language performance; the more the learners use metacognitive resources in their language learning, the more successful they were at performing language tasks. Fourth, our review convinced us that language proficiency, educational level, learning styles and first language strategy use/ knowledge all affect L2 metacognition. However, only a few studies currently exist which have focused on documenting the effects of each of these factors on metacognition.

Fifth, in the area of second language learning, questionnaire is the most used measure for metacognitive strategies. Although observational method, interviews and think aloud protocol have some priorities over the other methods such as self-report instruments, these tools for assessing metacognition have rarely been used by researchers. Indeed, only Lam (2009) has used observation (a synchronic measurement). Furthermore, only a few studies (e.g., Zhenton, 2012; Yau, 2009) have used both qualitative and quantitative tools to measure learners' metacognition in L2 learning. Sixth, the questionnaires used for the evaluation of metacognition seemed to cluster into two categories: skill-specific, and generic language learning. Some researchers used questionnaires which have been specifically designed for one of the language skills. For example Survey of Reading Strategies (SORS) (Mokhtari \& Sheorey, 2002) and Metacognitive Awareness Listening Questionnaire (MALQ) (Vandergrift, 2005, Vandergrift et al., 2006) are skill-specific questionnaire. Researchers have also adapted a questionnaire from a general language learning questionnaire or a general metacognitive instrument such as Metacognitive Awareness Inventory (MAI) (Schraw \& Dennison, 1994) and Strategy Inventory for Language Learning (SILL) (Oxford, 1990). It is worth noting that most of the questionnaire studies have used SILL (the metacognitive section) to measure metacognition. Although it has strong reliability, and is widely used, 
it should be cautioned that, when it is applied to a specific language skill, it may need to be modified as it has been designed for general L2 learning. Seventh, most of the research on metacognition has focused on reading and listening skills while relatively little research has dealt with the role of metacognition in the development of speaking and writing skills.

This study has several important implications for language teaching and learning. Learners' metacognition can be developed through pedagogical interventions. Teachers can get students involved in activities and process-based lessons which could lead them to develop their metacognitive knowledge in language learning. It is very worthwhile for the teachers to understand the importance of metacognition in language learning because it helps learners to become autonomous and self-regulated language learners. Furthermore, in order to enhance students' metacognitive knowledge, teachers should focus on both teaching language content and teaching the ways and processes of learning. This review study also forwards several suggestions for further research. It seems essential to investigate metacognitive strategies in relation to individual differences such as gender, personality traits, intelligence, self-efficacy and attributions. Further investigation is also needed to evaluate metacognition through several measurement tools; it is essential to conduct studies which involve the use of both synchronic instruments (think aloud and observation) and self-reports (questionnaire and interview), or the combination of both quantitative and qualitative tools. Finally, since almost all of the existing experimental research has addressed short-term effects, it seems necessary do more research in which the maintenance of metacognition is investigated over longer periods.

\section{References}

Bruen, J. (2001). Strategies for success: Profiling the effective learner of German. Foreign language annals, 34(3), 216-225. http://dx.doi.org/10.1111/j.1944-9720.2001.tb02403.x

Carrell, P. L. (1998). Can reading strategies be successfully taught? Australian Review of Applied Linguistics, 21, $1-20$.

Chamot, A. U. (2005). Language learning strategy instruction: Current issues and research. Annual Review of Applied Linguistics, 25(1), 112-130. http://dx.doi.org/10.1017/S0267190505000061

Chamot, A. U., \& El-Dinary, P. B. (1999). Children's learning strategies in language immersion classrooms. The Modern Language Journal, 83(3), 319-338. http://dx.doi.org/10.1111/0026-7902.00025

Chamot, A. U., \& Kupper, L. (1989). Learning strategies in foreign language instruction. Foreign language annals, 22(1), 13-22. http://dx.doi.org/10.1111/j.1944-9720.1989.tb03138.x

Chen, M. L. (2009). Influence of grade level on perceptual learning style preferences and language learning strategies of Taiwanese English as a foreign language learners. Learning and Individual Differences, 19(2), 304-308. http://dx.doi.org/10.1016/j.lindif.2009.02.004

Cohen, A. D. (1996). Verbal reports as a source of insights into second language learner strategies. Applied Language Learning, 7, 5-24.

Cohen, A. D. (1998). Strategies in learning and using a second language. New York, NY: Longman.

Cohen, A. D., \& Aphek, E. (1981). Easifying second language learning. Studies in second language acquisition, 3(2), 221-236. http://dx.doi.org/10.1017/S0272263100004198

Cohen, A. D., \& Macaro, E. (2007). Language learner strategies: Thirty years of research and practice. Oxford University Press Oxford, UK.

Cohen, A. D., Weaver, S. J., \& Li, T. Y. (1998). The impact of strategies-based instruction on speaking a foreign language. In A. D. Cohen (Ed.), Strategies in learning and using a second language (pp. 107-156). Essex, England: Longman.

Creswell, J. (1994). Research design qualitative and quantitative approaches. London: Sage.

Cross, J. (2010). Raising L2 listeners' metacognitive awareness: A sociocultural theory perspective. Language Awareness, 19(4), 281-297. http://dx.doi.org/10.1080/09658416.2010.519033

Cross, J. (2011). Metacognitive instruction for helping less-skilled listeners. ELT Journal, 65(4), 408-416. http://dx.doi.org/10.1093/elt/ccq073

Dochy, F., Segers, M., Van den Bossche, P., \& Gijbels, D. (2003). Effects of problem-based learning: A meta-analysis. Learning and Instruction, 13(5), 533-568. http://dx.doi.org/10.1016/S0959-4752(02)00025-7

Dornyei, Z. (2006). Individual differences in second language acquisition. AILA review, 19(1), 42-68. 
Ellis, R. (1994). The study of second language acquisition. Oxford, UK: Oxford University Press.

Flavell, J. H. (1976). Metacognitive aspects of problem solving. In L. B. Resnick (Ed.), The nature of intelligence (pp. 231-235). Hillsdale, NJ: Erlbaum.

Flavell, J. H. (1979). Metacognition and cognitive monitoring: A new area of cognitive-developmental inquiry. American psychologist, 34(10), 906. http://dx.doi.org/10.1037/0003-066X.34.10.906

Georghiades, P. (2004). From the general to the situated: Three decades of metacognition. International Journal of Science Education, 26(3), 365-383. http://dx.doi.org/10.1080/0950069032000119401

Goh, C. (1997). Metacognitive awareness and second language listeners. ELT Journal, 51(4), 361-369. http://dx.doi.org/10.1093/elt/51.4.361

Goh, C. (2008). Metacognitive Instruction for Second Language Listening Development Theory, Practice and Research Implications. RELC Journal, 39(2), 188-213. http://dx.doi.org/10.1177/0033688208092184

Goh, C., \& Taib, Y. (2006). Metacognitive instruction in listening for young learners. ELT Journal, 60(3), 222-232. http://dx.doi.org/10.1093/elt/ccl002

Graham, S., \& Macaro, E. (2008). Strategy Instruction in Listening for Lower-Intermediate Learners of French. Language learning, 58(4), 747-783. http://dx.doi.org/10.1111/j.1467-9922.2008.00478.x

Green, S. B., \& Salkind, N. J. (2005). Using SPSS for windows and macintosh: Analyzing and understanding data (4th ed.). New Jersey: Pearson Prentice Hall.

Green, S. B., \& Salkind, N. J. (Eds.) (2005). Using SPSS for Windows and Macintosh-Analyzing and understanding data (4th ed.). London: Pearson/Prentice Hall.

Hong-Nam, K., \& Leavell, A. G. (2006). Language learning strategy use of ESL students in an intensive English learning context. System, 34(3), 399-415. http://dx.doi.org/10.1016/j.system.2006.02.002

Hong-Nam, K., \& Leavell, A. G. (2007). A comparative study of language learning strategy use in an EFL context: Monolingual Korean and bilingual Korean-Chinese university students. Asia Pacific Education Review, 8(1), 71-88. http://dx.doi.org/10.1007/BF03025834

Hsiao, T. Y., \& Oxford, R. L. (2002). Comparing theories of language learning strategies: A confirmatory factor analysis. The Modern Language Journal, 86(3), 368-383. http://dx.doi.org/10.1111/1540-4781.00155

Jacobs, J. E., \& Paris, S. G. (1987). Children's metacognition about reading: Issues in definition, measurement, $\begin{array}{llll}\text { and instruction. } & \text { Educational 25s-278. }\end{array}$ http://dx.doi.org/10.1080/00461520.1987.9653052

Kern, R. G. (1989). Second language reading strategy instruction: Its effects on comprehension and word inference ability. The Modern Language Journal, 73(2), 135-149. http://dx.doi.org/10.1111/j.1540-4781.1989.tb02535.x

Khaldieh, S. A. (2000). Learning Strategies and Writing Processes of Proficient vs. Less-Proficient1 Learners of Arabic. Foreign language annals, 33(5), 522-533. http://dx.doi.org/10.1111/j.1944-9720.2000.tb01996.x

Khalil, A. (2005). Assessment of language learning strategies used by Palestinian EFL learners. Foreign language annals, 38(1), 108-117. http://dx.doi.org/10.1111/j.1944-9720.2005.tb02458.x

Lai, Y. C. (2009). Language learning strategy use and English proficiency of university freshmen in Taiwan. TESOL quarterly, 43(2), 255-280. http://dx.doi.org/10.1002/j.1545-7249.2009.tb00167.x

Lam, W., \& Wong, J. (2000). The effects of strategy training on developing discussion skills in an ESL classroom. ELT Journal, 54(3), 245-255. http://dx.doi.org/10.1093/elt/54.3.245

Lam, W. Y. (2009). Examining the effects of metacognitive strategy instruction on ESL group discussions: A synthesis of approaches. Language Teaching Research, 13(2), 129-150. http://dx.doi.org/10.1177/1362168809103445

Lawson, M., \& Hogben, D. (1998). Learning and recall of foreign-language vocabulary: Effects of a keyword strategy for immediate and delayed recall. Learning and Instruction, 8(2), 179-194. http://dx.doi.org/10.1016/S0959-4752(97)00016-9

Liu, H. J. (2008). A study of the interrelationship between listening strategy use, listening proficiency levels, and learning style. ARECLS, 5, 84-104.

Macaro, E. (2006). Strategies for language learning and for language use: Revising the theoretical framework. 
The Modern Language Journal, 90(3), 320-337. http://dx.doi.org/10.1111/j.1540-4781.2006.00425.x

Malcolm, D. (2009). Reading strategy awareness of Arabic-speaking medical students studying in English. System, 37(4), 640-651. http://dx.doi.org/10.1016/j.system.2009.09.008

Manfred, W. M. (2007). The relationships between the use of metacognitive language-learning strategies and language-learning motivation among Chinese-speaking ESL learners at a vocational education institute in Hong Kong. Asian EFL Journal, 9(3), 93-117.

McMullen, M. G. (2009). Using language learning strategies to improve the writing skills of Saudi EFL students: Will it really work? System, 37(3), 418-433. http://dx.doi.org/10.1016/j.system.2009.05.001

Mokhtari, K., \& Reichard, C. (2004). Investigating the strategic reading processes of first and second language readers in two different cultural contexts. System, 32(3), 379-394. http://dx.doi.org/10.1016/j.system.2004.04.005

Moradi, K. (2013). The Impact of Listening Strategy Instruction on Academic Lecture Comprehension: A Case of Iranian EFL Learners. Procedia-Social and Behavioral Sciences, 70, 406-416. http://dx.doi.org/10.1016/j.sbspro.2013.01.078

Nakatani, Y. (2005). The Effects of Awareness-Raising Training on Oral Communication Strategy Use. The Modern Language Journal, 89(1), 76-91. http://dx.doi.org/10.1111/j.0026-7902.2005.00266.x

Naughton, D. (2006). Cooperative strategy training and oral interaction: Enhancing small group communication in the language classroom. The Modern Language Journal, 90(2), 169-184. http://dx.doi.org/10.1111/j.1540-4781.2006.00391.x

Nguyen, L. T. C., \& Gu, Y. (2013). Strategy-based instruction: A learner-focused approach to developing learner autonomy. Language Teaching Research, 17(1), 9-30. http://dx.doi.org/10.1177/1362168812457528

Nisbet, J., \& Shucksmith, J. (1986). Learning strategies. Taylor \& Frances/Routledge.

Norris, J. M., \& Ortega, L. (2001). Does Type of Instruction Make a Difference? Substantive Findings From a $\begin{array}{lllll}\text { Meta-analytic } & \text { Review. } & \text { Language }\end{array}$ http://dx.doi.org/10.1111/j.1467-1770.2001.tb00017.x

Nunan, D. (1997). Strategy training in the language classroom: An empirical investigation. RELC Journal, 28(2), 56-81. http://dx.doi.org/10.1177/003368829702800204

O’Malley, J. M., \& Chamot, A. U. (1990). Learning strategies in second language acquisition. Cambridge University Press.

O’Malley, J. M., Chamot, A. U., \& Küpper, L. (1989). Listening comprehension strategies in second language acquisition. Applied linguistics, 10(4), 418-437. http://dx.doi.org/10.1093/applin/10.4.418

O’Malley, J. M., Chamot, A. U., Stewner-Manzanares, G., Kupper, L., \& Russo, R. P. (1985). Learning strategies used by beginning and intermediate ESL students. Language learning, 35(1), 21-46. http://dx.doi.org/10.1111/j.1467-1770.1985.tb01013.x

Oxford, R., \& Nyikos, M. (1989). Variables affecting choice of language learning strategies by university students. $\quad$ The Modern 291-300. http://dx.doi.org/10.1111/j.1540-4781.1989.tb06367.x

Oxford, R. L. (2011). Teaching and researching language learning strategies. Longman Harlow, UK.

Oxford, R. L., \& Ehrman, M. E. (1995). Adults' language learning strategies in an intensive foreign language program in the United States. System, 23(3), 359-386. http://dx.doi.org/10.1016/0346-251X(95)00023-D

Phakiti, A. (2003). A closer look at the relationship of cognitive and metacognitive strategy use to EFL reading $\begin{array}{llll}\text { achievement test } & \text { Language Testing, 20(1), 26-56. }\end{array}$ http://dx.doi.org/10.1191/02655322031t243oa

Pintrich, P. R. (2002). The role of metacognitive knowledge in learning, teaching, and assessing. Theory into practice, 41(4), 219-225. http://dx.doi.org/10.1207/s15430421tip4104_3

Pishghadam, R., \& Khajavy, G. H. (2012). Intelligence and metacognition as predictors of foreign language achievement: A structural equation modeling approach. Learning and Individual Differences. http://dx.doi.org/10.1016/j.lindif.2012.12.004

Plonsky, L. (2011). The Effectiveness of Second Language Strategy Instruction: A Meta-analysis. Language 
learning, 61(4), 993-1038. http://dx.doi.org/10.1111/j.1467-9922.2011.00663.x

Radwan, A. A. (2011). Effects of L2 proficiency and gender on choice of language learning strategies by university students majoring in English. Asian EFL Journal, 13(1), 114-162.

Rahimi, M., \& Katal, M. (2012). Metacognitive listening strategies awareness in learning English as a foreign language: A comparison between university and high-school students. Procedia-Social and Behavioral Sciences, 31, 82-89. http://dx.doi.org/10.1016/j.sbspro.2011.12.020

Rebecca, O. (1990). Language learning strategies: What every teacher should know. New York: Newbury House/Harper and Row.

Rivera-Mills, S. V., \& Plonsky, L. (2007). Empowering students with language learning strategies: A critical review of current issues. Foreign language annals, 40(3), 535-548. http://dx.doi.org/10.1111/j.1944-9720.2007.tb02874.x

Rossiter, M. J. (2003). The effects of affective strategy training in the ESL classroom. TESL-EJ, 7(2), 1-20.

Rubin, J. (1975). What the "good language learner" can teach us. TESOL quarterly, 41-51.

Schoonen, R., van Gelderen, A., Stoel, R. D., Hulstijn, J., \& de Glopper, K. (2011). Modeling the development of L1 and EFL writing proficiency of secondary school students. Language learning, 61(1), 31-79. http://dx.doi.org/10.1111/j.1467-9922.2010.00590.x

Schraw, G. (1994). The effect of metacognitive knowledge on local and global monitoring. Contemporary educational psychology, 19(2), 143-154. http://dx.doi.org/10.1006/ceps.1994.1013

Schraw, G. (2009). A conceptual analysis of five measures of metacognitive monitoring. Metacognition and Learning, 4(1), 33-45. http://dx.doi.org/10.1007/s11409-008-9031-3

Schraw, G., Crippen, K. J., \& Hartley, K. (2006). Promoting self-regulation in science education: Metacognition as part of a broader perspective on learning. Research in Science Education, 36(1-2), 111-139. http://dx.doi.org/10.1007/s11165-005-3917-8

Spada, N., \& Tomita, Y. (2010). Interactions between type of instruction and type of language feature: A Meta-Analysis. Language learning, 60(2), 263-308. http://dx.doi.org/10.1111/j.1467-9922.2010.00562.x

Swanson, H. L. (1990). Influence of metacognitive knowledge and aptitude on problem solving. Journal of educational psychology, 82(2), 306. http://dx.doi.org/10.1037/0022-0663.82.2.306

Taylor, A., Stevens, J., \& Asher, J. W. (2006). The effects of explicit reading strategy training on L2 reading comprehension. In J. Norris, \& L. Ortega (Eds.), Synthesizing research on language learning and teaching (pp. 213-244). Philadelphia: Benjamins.

Thompson, D. R. (2012). Promoting Metacognitive Skills in Intermediate Spanish: Report of a Classroom Research Project. Foreign language annals, 45(3), 447-462. http://dx.doi.org/10.1111/j.1944-9720.2012.01199.x

Van Gelderen, A., Schoonen, R., De Glopper, K., Hulstijn, J., Simis, A., Snellings, P., \& Stevenson, M. (2004). Linguistic Knowledge, Processing Speed, and Metacognitive Knowledge in First-and Second-Language Reading Comprehension: A Componential Analysis. Journal of educational psychology, 96(1), 19. http://dx.doi.org/10.1037/0022-0663.96.1.19

Vandergrift, L. (2002). 'It Was Nice to See That Our Predictions Were Right': Developing Metacognition in L2 Listening Comprehension. Canadian Modern Language Review/La Revue canadienne des langues vivantes, 58(4), 555-575. http://dx.doi.org/10.3138/cmlr.58.4.555

Vandergrift, L. (2003). From Prediction Through Reflection: Guiding Students. Through the Process of L2 Listening. Canadian Modern Language Review/La Revue canadienne des langues vivantes, 59(3), 425-440. http://dx.doi.org/10.3138/cmlr.59.3.425

Vandergrift, L. (2005). Relationships among motivation orientations, metacognitive awareness and proficiency in L2 listening. Applied linguistics, 26(1), 70-89. http://dx.doi.org/10.1093/applin/amh039

Vandergrift, L., \& Tafaghodtari, M. H. (2010). Teaching L2 learners how to listen does make a difference: An empirical study. Language learning, 60(2), 470-497. http://dx.doi.org/10.1111/j.1467-9922.2009.00559.x

Victori, M. (1999). An analysis of writing knowledge in EFL composing: A case study of two effective and two less effective writers. System, 27(4), 537-555. http://dx.doi.org/10.1016/S0346-251X(99)00049-4 
Wenden, A., \& Rubin, J. (1987). Learner Strategies in Language Learning. Englewood Cliffs. NY: Prentice Hall International.

Wenden, A. L. (1998). Metacognitive Knowledge and Language Learning. Applied linguistics, 19(4), 515-537. http://dx.doi.org/10.1093/applin/19.4.515

Yau, J. C. (2009). Reading characteristics of Chinese-English adolescents: Knowledge and application of strategic reading. Metacognition and Learning, 4(3), 217-235. http://dx.doi.org/10.1007/s11409-009-9046-4

Zenotz, V. (2012). Awareness development for online reading. Language Awareness, 21(1-2), 85-100. http://dx.doi.org/10.1080/09658416.2011.639893

Zhang, D., \& Goh, C. C. (2006). Strategy knowledge and perceived strategy use: Singaporean students' awareness of listening and speaking strategies. Language Awareness, 15(3), 199-119. http://dx.doi.org/10.2167/la342.0

Zhang, L. J. (2001). Awareness in reading: EFL students' metacognitive knowledge of reading strategies in an $\begin{array}{llll}\text { acquisition-poor environment. } & \text { Language } & \text { Awareness, } & \text { 10(4), }\end{array}$ http://dx.doi.org/10.1080/09658410108667039

\section{Copyrights}

Copyright for this article is retained by the author(s), with first publication rights granted to the journal.

This is an open-access article distributed under the terms and conditions of the Creative Commons Attribution license (http://creativecommons.org/licenses/by/3.0/). 